\title{
Evaluation of immunomodulatory activity of tenoxicam in mice
}

\author{
Fatima Nasim¹, Aqeel Javeed ${ }^{1 *}$, Muhammad Ashraf ${ }^{1}$, Aamir Ghafoor ${ }^{2}$ \\ ${ }^{1}$ Department of Pharmacology \& Toxicology, ${ }^{2}$ University Diagnostic Lab, University of Veterinary and Animal Sciences, Lahore, \\ Pakistan \\ *For correspondence: Email: aqeel.javeed@uvas.edu.pk Tel: +92429211449
}

Revised accepted: 11 April 2018

\begin{abstract}
Purpose: The present study was conducted to evaluate the effect of tenoxicam on cellular and humoral immunity.

Methods: Tenoxicam $(2.5-10 \mathrm{mg} / \mathrm{kg})$ was administered at three different doses to three groups of mice and the cellular immune responses were studied using delayed hypersensitivity response (DTH) and cyclophosphamide-induced neutropenia while the humoral immune response was evaluated using hemagglutination test and mice mortality ratio. Normal saline and cyclophosphamide were used as negative and positive controls, respectively.

Results: DTH assay resulted in a significant reduction in skin thickness $(p<0.05)$ for tenoxicam treated groups when compared to the negative control group at $24 h, 48 h$ and $72 h$ after administration of challenging dose of dinitrochlorobenzene (DNCB). Cyclophoshamide induced neutropenia showed a significant percentage reduction in total leukocyte count (TLC) and differential leukocyte count (DLC) i.e. lymphocytes and neutrophils $(p<0.05)$, but an increase in monocytes in all the treatment groups in the following order: $10 \mathrm{mg}>5 \mathrm{mg}>2.5 \mathrm{mg}>$ negative control group. A dose dependent reduction response was observed $(p<0.05)$ in haemagglutination assay (HA). In mice lethality test mortality ratios of $2.5 \mathrm{mg}$, $5 \mathrm{mg}, 10 \mathrm{mg}$ tenoxicam were $60 \%, 80 \%$ and $100 \%$, respectively, compared to $20 \%$ and $100 \%$ for normal saline group and cyclophosphamide, respectively

Conclusion: The results suggest that tenoxicam suppresses both cellular and humoral immunity in mice.
\end{abstract}

Keywords: Tenoxicam, Cellular immunity, Humoral immunity

\begin{abstract}
This is an Open Access article that uses a funding model which does not charge readers or their institutions for access and distributed under the terms of the Creative Commons Attribution License (http://creativecommons.org/licenses/by/4.0) and the Budapest Open Access Initiative (http://www.budapestopenaccessinitiative.org/read), which permit unrestricted use, distribution, and reproduction in any medium, provided the original work is properly credited.
\end{abstract}

Tropical Journal of Pharmaceutical Research is indexed by Science Citation Index (SciSearch), Scopus, International Pharmaceutical Abstract, Chemical Abstracts, Embase, Index Copernicus, EBSCO, African Index Medicus, JournalSeek, Journal Citation Reports/Science Edition, Directory of Open Access Journals (DOAJ), African Journal Online, Bioline International, Open-J-Gate and Pharmacy Abstracts

\section{INTRODUCTION}

Infiltration of blood leucocytes to an infected area in the body triggers inflammatory response. This response is initiated when body tissues are damaged by bacteria, trauma, toxins, heat, or any other agent [1]. Inflammatory mediators, which include prostaglandins, leukotrienes, histamines and bradykinins, secreted by the inflamed organs of the body propagate the inflammation [2]. In response to the inflammatory reactions, tissue manifests swelling pain, oedema and hyperthermia. By blocking the synthesis of inflammatory mediators, antiinflammatory drugs are able alleviate the inflammatory response. These anti-inflammatory 
drugs are mainly steroids and non-steroidal antiinflammatory drugs (NSAIDs). The NSAIDs has been categorized into different groups on the basis of their variable response and mode of action and exert their actions by blocking cyclooxygenase 1 and 2 (COX 1 and COX 2) enzymes [3]. The enzymatic inhibition of COX causes blocking of prostaglandins that modulate immunity through complicated communication with white blood cells and parenchymal cells in the inflamed organ [4]. Prostaglandins binding receptors involved in inflammation are also expressed throughout the immune system [5].

Oxicams, an important family from the nonsteroidal anti-inflammatory drugs, bind to plasma proteins and have weak acid characteristics. Tenoxicam is a new drug from this family which is used to treat many inflammatory disorders. It is often preferred due to less side effects and long half-life (67 h) as compared to other NSAIDs [6] and produces its anti-inflammatory and analgesic effects by inhibiting prostaglandins $\left(\mathrm{PGE}_{2}\right)$ [7]. Besides its role as an anti-inflammatory drug, an earlier study reported that tenoxicam suppresses the immune system of the subject by inhibiting in vitro functional chemotactic response of neutrophils and monocytes but a detailed work on its role on immune response is yet to be explored $[8,9]$. In this study, the cellular and humoral immunity response to tenoxicam was evaluated.

\section{EXPERIMENTAL}

The experimental research was performed in the Department of Pharmacology and Toxicology, University of Veterinary and Animal Sciences (UVAS) Lahore, Pakistan with the collaboration of University Diagnostic Laboratory, UVAS Lahore, Pakistan.

\section{Animals}

A total of 120 healthy albino mice (20 to $30 \mathrm{~g}$ ) were bought from the Department of Theriogenology, University of Veterinary and Animal Sciences (UVAS) Lahore. They were kept in the laboratory for acclimatization for $48 \mathrm{hrs}$ and then divided randomly into five groups for each test, nourished with standard pellet diet and water during whole experimental period. All the ethical issues were considered as mentioned in the institutional guidelines regarding the experimental use of mice.

\section{Materials}

The following chemicals were used: tenoxicam (Zhejiang Chemicals Imp \& Exp. Corp,
Hangzhou, China), normal saline (Medipak Ltd., Lahore, Pakistan), dinitrochlorobenzene (DNCB) (Alfa Aesar, Heysham, Lancaster, England), cyclophosphamide injection in powder form (cyclomide) (Pharmedic laboratory Pvt. Ltd Lahore, Pakistan), acetone and ether solvent (Sigma-Aldrich Laborchemikalien $\mathrm{GmbH}$ Seelze, Germany) and phosphate buffer saline (PBS) (Bioplus Fine Research Chemicals, Madison, USA).

\section{Experimental design}

Tenoxicam was administered at three different doses to mice and the cellular immune response was studied using delayed hypersensitivity test (DTH) and neutropenic effect of cyclophosphamide while the humoral immune response was evaluated using hemagglutination test and mice mortality test. Animals treated with normal saline and cyclophoshamide served as negative and positive control groups, respectively.

\section{Delayed type hypersensitivity (DTH) assay}

A total of 25 mice organized into five groups ( $A$, $B, C, D$ and $E$; five mice in each group) were used for the delayed type hypersensitivity (DTH) assay as previously reported [10]. On the $1^{\text {st }}$ day of experiment tenoxicam at the doses of $2.5 \mathrm{mg}$, $5 \mathrm{mg}$ and $10 \mathrm{mg}$ in group C, D and $\mathrm{E}$ respectively were administered intraperitoneally (i.p.) while to the negative control group (group A) only normal saline was administered. Cyclophoshamide, at dose of $150 \mathrm{mg} / \mathrm{kg}$, was given i.p. to the positive control group (group B). On the $2^{\text {nd }}$ day of experiment (i.e. one day after the treatment with tenoxicam), hair were removed (shaved) from left side of all the mice with the help of a scissor. Measurement of skin thickness was taken with the help of digital vernier calliper $(\mathrm{mm})$. Dinitrochlorobenze (DNCB, 2 \%) solution in acetone at measured amount of $0.1 \mathrm{ml}$ was applied to the shaved area of the skin $\left(4 \mathrm{~cm}^{2}\right)$ marked with permanent marker. After the $12^{\text {th }}$ day post sensitization ( $14^{\text {th }}$ day of experiment) skin thickness of mice was measured from the shaved area and a challenging dose $(0.2 \mathrm{ml})$ of 2 $\%$ DNCB in acetone was applied. Skin thickness was measured again using a digital vernier callipers (mm) after 24, 48 and $72 \mathrm{~h}$.

\section{Cyclophosphamide induced neutropenia assay}

All the experimental animals (20 albino mice) were weighed and sorted out into four groups ( $A$, $B, C$ and $D$ ) with each group having five mice [11]. Treatment groups B, C and D were 
administered with tenoxicam $(2.5 \mathrm{mg}, 5 \mathrm{mg}$ and $10 \mathrm{mg}$ respectively) intraperitoneally daily for total of 13 days while the mice for the control group (group A) were given saline solution for the same duration. On $10^{\text {th }}$ day of experiment 200 $\mathrm{mg} / \mathrm{kg}$ cyclophosphamide was administered subcutaneously once to both tenoxicam treated groups and to the control group. Blood sample was collected and total leukocyte count (TLC) as well as differential leukocyte count (DLC) for lymphocytes, monocytes and neutrophils were performed by using automatic haematological analyzer (Dawn Analytical Supplies \& Calibrators) prior to the administration of cyclophosphamide. On day 3 after injection of cyclophoshamide i.e. $13^{\text {th }}$ day (last day) again blood samples were analyzed for TLC and DLC. Percentage values of total and differential leucocytes in tenoxicam treated groups and the control group were compared prior to and after the cyclophosphamide administration.

\section{Haemagglutination assay}

Five groups of mice $(A, B, C, D$, and $E$; five mice in each group) were selected for assay [12]. Each animal in the tenoxicam treated group (C, $\mathrm{D}$ and $\mathrm{E})$ was administered tenoxicam $(2.5 \mathrm{mg}$, $5 \mathrm{mg}$ and $10 \mathrm{mg}$ ) respectively through intraperitoneal route daily for 28 days. Each of the mouse in groups $A$ and $B$ was administered normal saline and cyclophoshamide $(150 \mathrm{mg} / \mathrm{kg})$ i.p. for the same duration (28 days) while all the mice in treatment groups and control groups were injected intraperitoneally with $0.5 \times 10^{9}$ sheep's red blood cells/ mouse i.p in phosphate buffer saline on $14^{\text {th }}$ and $21^{\text {st }}$ day of the test. On last day of treatment ( $28^{\text {th }}$ day) blood serum was separated from blood and HA titre was performed. The maximum serum dilution (minimum volume of serum) in which haemagglutination appeared was known as haemagglutination $(\mathrm{HA})$ titre.

\section{Mice lethality test}

This test was done with a total of 25 mice, which were arranged into five groups $(A, B, C, D$ and $E)$ each having five mice [13]. All the mice in the tenoxicam treated groups (C, D and $E$ ) were received daily doses of $2.5 \mathrm{mg}, 5 \mathrm{mg}$ and $10 \mathrm{mg}$ of tenoxicam intraperitoneally for 21 days while those in groups $A$ and $B$ were administered with normal saline and cyclophoshamide $(150 \mathrm{mg} / \mathrm{kg})$ i.p. respectively. All the experimental mice were immunized with $0.2 \mathrm{ml}$ haemorrhagic septicemia vaccine (HS vaccine) subcutaneously on the 7th and $17^{\text {th }}$ day of the test. Challenging dose of
$0.2 \mathrm{ml}$ of Pasteurella multocida culture $\left(10^{7}\right.$ cells per $\mathrm{ml}$ ) was given to all of the mice subcutaneously on the $21^{\text {st }}$ day of experiment. The mice were then observed for three days and the mortality rate calculated as reported previously [13].

\section{Statistical analysis}

All the results were assessed by one way analysis of variance (ANOVA) followed by Duncan's post-test. Results were compared with negative control group at significance level of ${ }^{*} p$ $<0.05,{ }^{* *} p<0.01$ and ${ }^{* * *} p<0.001$. Statistical Package for Social Sciences (SPSS for Windows version 16, SPSS Inc, and Chicago, IL, USA) was used.

\section{RESULTS}

Delayed type hypersensitivity showed a significant difference between the mean values of skin thickness of all the treatment and control groups at one, two and three days intervals $(P<0.05)$. The percentage reduction in the mean skin thickness was dose dependent. Maximum percentage reduction was observed in group $\mathrm{E}$ and the lowest was observed in group $C$ when compared with the negative control group (Table 1). Mice of group $B$ showed the maximum change in skin thickness in comparison with the mice treated with tenoxicam.

In cyclophosphamide induced neutropenia assay, a dose dependent reduction response was observed in tenoxicam treated groups. Group D showed a maximum reduction in TLC and DLC when compared to the control group (Figure 1). Group B showed minimum reduction of cell count (lymphocytes, monocytes and neutrophils) in comparison to the control group (figure 2). Percentage reduction for TLC in mice (A, B, C and D) was $62.67 \%, 64.47 \%, 70.11 \%$ and $73.2 \%$ respectively while decrease in differential leucocytes count (DLC i.e. lymphocytes, neutrophils and monocytes ) in the group A was $12.72 \%, 31.2 \%$ and $30.28 \%$, in group B was $14.05 \%, 35.5 \%$ and $37.1 \%$, in group C was $21.1 \%, 37.6 \%$ and $55.4 \%$, and in group D was $23.4 \%, 62.6 \%$ and $54.7 \%$ after cyclophoshamide administration.

TLC decreases after administration of cyclophoshamide in all the control and tenoxicam treated groups .Data is presented as mean and standard deviation. 
Table 1: Effect of tenoxicam on skin thickness

\begin{tabular}{|c|c|c|c|c|c|}
\hline \multicolumn{3}{|c|}{ Negative } & \multicolumn{3}{|c|}{ Tenoxicam groups } \\
\hline $\begin{array}{l}\text { Time for skin } \\
\text { thickness } \\
\text { measurement }\end{array}$ & $\begin{array}{l}\text { Control group } \\
\text { (Normal } \\
\text { Saline) }\end{array}$ & $\begin{array}{c}\text { Positive control } \\
\text { group } \\
\text { (cyclophosphamide) }\end{array}$ & $2.5 \mathrm{mg} / \mathrm{kg}$ & $5 \mathrm{mg} / \mathrm{kg}$ & $10 \mathrm{mg} / \mathrm{kg}$ \\
\hline $\begin{array}{l}\text { Before } \\
\text { challenge with } \\
\text { DNCB }\end{array}$ & $0.59 \pm 0.055$ & $0.53 \pm 0.067$ & $0.64 \pm 0.042$ & $0.64 \pm 0.042$ & $0.56 \pm 0.072$ \\
\hline $\begin{array}{l}\text { After } 24 \mathrm{~h} \\
\text { After } 48 \mathrm{~h} \\
\text { After } 72 \mathrm{~h}\end{array}$ & $\begin{array}{l}0.77 \pm 0.038^{\star} \\
0.77 \pm 0.037^{\star} \\
0.76 \pm 0.030^{\star}\end{array}$ & $\begin{array}{l}0.62 \pm 0.051^{+} \\
0.58 \pm 0.053^{+} \\
0.56 \pm 0.043^{+}\end{array}$ & $\begin{array}{l}0.80 \pm 0.023^{\star} \\
0.78 \pm 0.035^{\star} \\
0.77 \pm 0.030\end{array}$ & $\begin{array}{l}0.75 \pm 0.045 \\
0.73 \pm 0.039 \\
0.71 \pm 0.038\end{array}$ & $\begin{array}{l}0.64 \pm 0.065 \\
0.63 \pm 0.069 \\
0.59 \pm 0.055\end{array}$ \\
\hline
\end{tabular}

Values were shown as mean value \pm standard deviation (SD) $n=5$ in skin thickness, the change in skin thickness of low, standard and high dose tenoxicam treated group (2.5 mg, $5 \mathrm{mg}$ and $10 \mathrm{mg}$ ), negative and positive control group was significant at ${ }^{*} p<0.05$ when compared to the normal saline group. ${ }^{+} p<0.05$ when compared to the positive control group. $p<0.05$ when compared to the low dose of tenoxicam (2.5 $\mathrm{mg})$

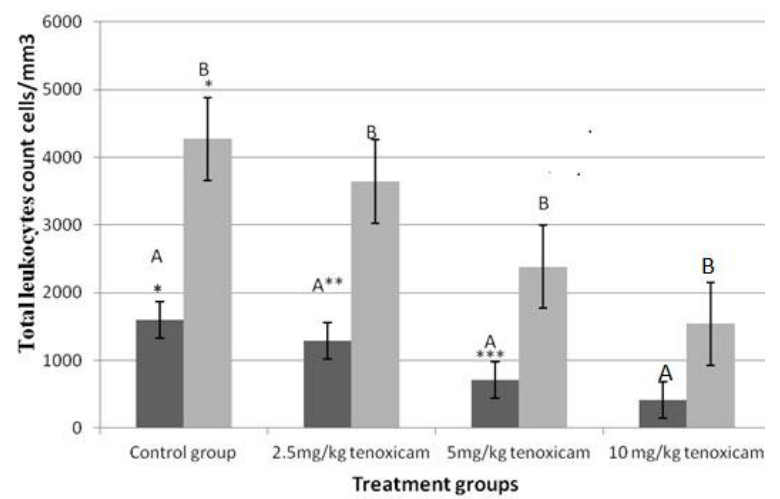

Figure 1: Total leukocyte count (TLC) before and after cyclophoshamide administration. $\mathrm{A}=$ After cyclophoshamide administration, $B=$ Before cyclophoshamide administration

High dose tenoxicam group showed the maximum decrease as compared to low $(2.5 \mathrm{mg})$ and standard (5 mg) tenoxicam treated group. Control group showed minimum change in TLC. Control group showed significance at $p<0.05$, low dose group at $p<0.01$ and high dose group at $p<0.001$.

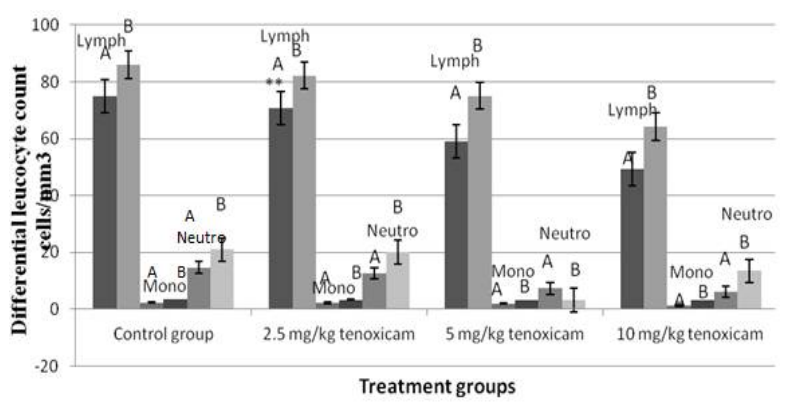

Figure 2: Differential leukocyte count (DLC) decreases after administration of cyclophoshamide in all the control and tenoxicam treated groups. $\mathbf{A}=$ After cyclophoshamide administration, $\mathbf{B}=$ Before cyclophoshamide administration

DLC decreases after administration of cyclophoshamide in all the control and tenoxicam treated groups. Data is presented as mean and standard deviation. High dose tenoxicam group showed the maximum decrease as compared to low $(2.5 \mathrm{mg})$ and standard $(5 \mathrm{mg})$ tenoxicam treated group. Control group showed minimum change in DLC. Tenoxicam at low dose was significant at $p<0.01$. All the other results were significant at $p<0.05$ except the monocytes level after cyclophoshamide administration

The value of HA titre revealed that the high dose group $E$ in the experiment showed the minimum HA titre. Low dose group $\mathrm{C}$ showed maximum titre among the treated tenoxicam groups when compared to the negative saline group. Cyclophosphamide group and group $\mathrm{E}$ showed equal mean values of HA titre (Table 2).

Table 2: Mean values of HA titre of control and tenoxicam treated groups

\begin{tabular}{lc}
\hline Group & Mean HA titre value \\
\hline $\begin{array}{l}\text { Negative control group } \\
\text { (Normal Saline) }\end{array}$ & $57.6 \pm 14.31^{*}$ \\
$\begin{array}{l}\text { Positive control group } \\
\text { (cyclophosphamide) }\end{array}$ & $2.4 \pm 1.67^{+}$ \\
$2.5 \mathrm{mg} / \mathrm{kg}$ tenoxicam & $44.8 \pm 17.52$ \\
$5 \mathrm{mg} / \mathrm{kg}$ tenoxicam & $16.8 \pm 9.9$ \\
$10 \mathrm{mg} / \mathrm{kg}$ tenoxicam & $2.4 \pm 0.89$ \\
\hline$H A$ mean \pm standard deviation $(\mathrm{SD}), n=5$, the change \\
in HA titre (2.5 mg, $5 \mathrm{mg}$ and $10 \mathrm{mg})$ tenoxicam groups \\
was significant at ${ }^{*} p<0.05$ compared to the normal \\
saline group. ${ }^{+} p<0.05$ when compared to the \\
cyclophosphamide group. $p<0.05$ when compared to \\
the low dose tenoxicam group $(2.5 \mathrm{mg})$
\end{tabular}

In the mice lethality test, the mice treated with high dose of tenoxicam had comparable mortality ratio when compared to the positive control group (Table 3).

\section{DISCUSSION}

In this study tenoxicam suppressed both the cellular and humoral immunity in mice in response to DTH and cyclophoshamide induced neutropenia. The maximum inflammatory response was observed in DTH against DNCB 
Table 3: Effect of tenoxicam and control groups on mice lethality

\begin{tabular}{|c|c|c|c|c|c|}
\hline \multirow[b]{2}{*}{ Group } & \multicolumn{3}{|c|}{ Number of mice that died } & \multirow[b]{2}{*}{$\begin{array}{c}\text { Total } \\
\text { number of } \\
\text { mice died } \\
\text { after } 72 \\
\text { hours }\end{array}$} & \multirow[b]{2}{*}{$\begin{array}{c}\text { Percentage } \\
\text { mortality ratio }\end{array}$} \\
\hline & $\begin{array}{c}\text { Between } \\
\text { 0-24 hours }\end{array}$ & $\begin{array}{c}\text { Between } \\
24-48 \\
\text { hours }\end{array}$ & $\begin{array}{c}\text { Between } \\
48-72 \\
\text { hours }\end{array}$ & & \\
\hline Normal saline & - & 1 & - & $1 / 5$ & $20 \%$ \\
\hline Cyclophosphamide & 3 & 1 & 1 & $5 / 5$ & $100 \%$ \\
\hline $2.5 \mathrm{mg} / \mathrm{kg}$ tenoxicam & - & 3 & - & $3 / 5$ & $60 \%$ \\
\hline $5 \mathrm{mg} / \mathrm{kg}$ tenoxicam & - & 4 & - & $4 / 5$ & $80 \%$ \\
\hline $10 \mathrm{mg} / \mathrm{kg}$ tenoxicam & 4 & 1 & - & $5 / 5$ & $100 \%$ \\
\hline
\end{tabular}

in negative control group while the minimum response was observed in the mice treated with tenoxicam high dose (group E).

Tenoxicam has demonstrated inhibition of the production of prostaglandins from inflammatory tissues $[14,15]$. Less production of inflammatory mediators could be the reason of decreased response to DNCB. Previously research described the effect of aspirin on immune cells of mice; treatment with aspirin in vivo has the ability to reduce the number of macrophages and nonopsonic phagocytosis $[16,17]$.

Cyclophoshamide used in this experiment is a pro-drug which produces active alkylating species after metabolic transformation. These species attach to DNA, causing strand breakage and cross linking, and resulting in death of fast replicating cells [18]. The observed dose dependent percentage reduction in total leucocytes count (TLC) in cyclophosphamide treated animals observed in groups $(A, B, C$ and D) was dose dependent. This suppression of leucocytes was prominent for group D. Reduction in neutrophil count suggests neutropenia which consequently results in immunosuppression. Humoral response works by the continuous specialized conversion of memory $B$ cells to antibody-secreting plasma cells. Antibodies defend the body against antigen [19]. Production of antibodies against the antigen presented to immune system is a manifestation of active humoral immunity. Antibodies against sheep RBCs were produced and measured by haemagglutination assay. An effect of tenoxicam on humoral arm of immune system was observed by haemagglutination assay. The titre was high in negative control group as compared to treated groups. Results showed that tenoxicam at high dose (group E) had a decreased HA titre which could be due to decreased production of immunoglobulins [20]. Humoral antibodies detected in response to killed Pasteurella multocida vaccine showed that the post-challenge death ratio was high in tenoxicam treated groups as compared to the control group. Possibly this could be due to less production of antibodies against Pasteurella multocida by $\mathrm{B}$ lymphocytes of mice at high dose (10 mg/kg body weight).

\section{CONCLUSION}

Tenoxicam is known to possess analgesic, antiinflammatory and anti-pyretic activity. This study has shown that it also possesses immunosuppressive activity (both cellular and humoral arms of immunity). Thus the compound may be of useful in organ transplant rejection and autoimmune diseases.

\section{DECLARATIONS}

\section{Acknowledgement}

We are thankful to the Department of Pharmacology and Toxicology, University of Veterinary and Animal Sciences, Lahore Pakistan to provide the financial assistance to complete the research work.

\section{Conflict of interest}

No conflict of interest associated with this work.

\section{Contribution of authors}

We declare that this work was done by the authors mentioned in this article and all liabilities regarding claims relating to the content of this article will be borne by the authors. Aqeel Javeed conceived and designed the study. Fatima Nasim collected, analysed, and wrote the manuscript with the collaboration of Aamir Ghafoor and Muhammad Ashraf. All authors read and approved the manuscript for publication.

\section{REFERENCES}

1. Libby $P$. Inflammatory mechanisms: the molecular basis of inflammation and disease. Nutr Rev 2007; 65 (12): 140-156.

Trop J Pharm Res, September 2018; 17(9): 1815 
2. Heo SJ, Jang J, Ye BR, Kim MS, Yoon WJ, Oh C, Kang $D H$, Lee JH, Kang MC, Jeon YJ et al. Chromene suppresses the activation of inflammatory mediators in lipopolysaccharide - stimulated RAW 264.7 cells. Food Chem Toxicol 2014; 67: 169-175. doi: 10.1016

3. Liggett JL, Choi CK, Donnell RL, Kihm KD, Kim JS, Min KW, Noegel AA, Baek SJ. Non-steroidal antiinflammatory drug suppresses structural protein Nesprin-2 expression in colorectal cells. Biochem Biophys Acta 2014; 1840 (1): 322-331.

4. Tilley SL, Coffman TM, Koller BH. Mixed messages: modulation of inflammation and immune responses by prostaglandins and thromboxanes. J Clin Invest 2001; 108 (1): 15-23.

5. Hata AN, Breyer RM. Pharmacology and signalling of prostaglandin receptors: multiple roles in inflammation and immune modulation. Pharmacol Ther 2004; 103 (2): 147-166.

6. Nilsen OG. Clinical pharmacokinetics of tenoxicam. Clin Pharmacokinet 1994; 26 (1): 16-43.

7. Celebioglu B, Eslambouli NR, Olcay E, Atakan S. The effect of tenoxicam on intraperitoneal adhesions and prostaglandin E2 levels in mice. Anesth Analg 1999; 88 (4): 939-942.

8. Yip HC, Karulin AY, Tary- Lehmann M, Hesse MD, Radeke H, Heeger PS, Trezza RP, Heinzel FP, Forthuber T, Lehmann PV. Adjuvant- guided type -1 and type-2 immunity: infectious/ non-infectious dichotomy defines the class of response. J immunol. 1999; 162 (7): 3942-3949.

9. Scheinberg MA, Santoro J, Sanchez ML. Effect of tenoxicam on inflammation and immune cellular function. Braz J Med Biol Res 1990; 23 (11):1143-1148.

10. Sajid MS, Iqbal Z, Muhammad G, Sandhu MA, Khan $M N$, Saqib $M$, lqbal MU. Effect of ivermectin on the cellular and humoral immune responses of rabbits. Life Sci 2007; 80(21): 1966-1970.
11. Asad M, Srivathsa B. Immunomodulatory activity of cod liver oil. Iran J Pharmacol Ther 2011; 11(1):20-25.

12. Fluzele SV, Satturwarv PM, Joshi SB, Dorle AK. Study of the immunomodulatory activity of Haridradighrita in rats. Indian J Pharmacol 2003; 35: 51-54.

13. Sudha P, Asdaq SM, Dhamingi SS, Chandrakala GK. Immunomodulatory activity of methanolic leaf extract of Moringa oleifera in animals. Indian J Physiol Pharmacol 2010; 54(2): 133-140.

14. Gonzalez JP, Todd PA. Tenoxicam: A preliminary review of its pharmacodynamic and pharmacokinetic properties and therapeutic efficacy. Drugs 1987; 34(3): 289-310.

15. Maffei Facino RM, Carini M, Saibene L. Scavenging of free radicals by tenoxicam: a participating mechanism in the antirheumatic/antiinflammatory efficacy of the drug. Arch Pharm 1996; 329(10): 457-463.

16. Javeed A, Hou Y, Duan K, Zhang B, Shen H, Cao $Y$, Zhao $Y$. Aspirin significantly decreases the nonopsonic phagocytosis and immunogenicity of macrophages in mice. Inflam Res 2011; 60(4): 389-398.

17. Hussain M, Javeed A, Ashraf M, Zhao Y, Mukhtar MM, Rehman MU. Aspirin and immune system. Int Immunopharmacol 2012; 12: 10-20.

18. Zuluaga AF, Salazar BE, Rodriguez CA, Zapata $A X$, Agudelo $M$, Vesga $O$. Neutropenia induced in outbred mice by a simplified low-dose cyclophosphamide regimen: characterization and applicability to diverse experimental models of infectious diseases. BMC. Infect Dis 2006; 6:55.

19. Slifka MK, Antia R, Whitmire JK, Ahmed R. Humoral immunity due to long-lived plasma cells. Immunity 1998; 8(3): 363-372.

20. Seung E, Tager AM. Humoral immunity in humanized mice: a work in progress. $J$ Infect Dis 2013; 208: 155159. 